\title{
Challenges for Calla Growers in the Unsubsidized New Zealand Export Market
}

\author{
John Clemens, ${ }^{1}$ \\ E wen A. Cameron, ${ }^{2}$ and \\ Richard C. Funt ${ }^{3}$
}

AdDITIONAL INDEX WORDS. Zantedeschia, industry organization, survey, nerine

\begin{abstract}
Summary. Calla (Zantedeschia Spreng.) growers were studied as members of an expanding sector in the $\mathrm{N}$ ew Zealand floricultural industry. The calla sector is characterized by diverse-size firms scattered throughout the two main islands of $\mathrm{N}$ ew Z ealand. G rowers differ in their skill and experience with calla production. Problems are both growerspecific (e.g., control of diseases, postharvest disorders) and sectorwide. Examples of the latter include the prioritizing and funding research, interacting with science organizations and planning sector marketing strategy. Both sets of problems have been exacerbated by the progressive withdrawal of research and extension support services traditionally provided by government agencies. There is competition between the floriculture industry and calla sector-based grower organizations. The leadership role of a strong grower organization, in this case the $\mathbf{N}$ ew Zealand $\mathrm{C}$ alla $\mathrm{C}$ ouncil (N ZC C ), is seen as an essential forum for growers, and as the link between growers, exporter organizations, scientists and central government. G ood communications between the industry organization and growers is essential to identify and prioritize
\end{abstract}

\footnotetext{
Financial assistance of the Agricultural and $\mathrm{M}$ arketing Research and D evelopment Trust, and research assistance of M.A. Loncke and E. Gosens, Agricultural $U$ niversity of Wageningen are acknowledged. The cost of publishing this paper was defrayed in part by the payment of page charges. Under postal regulations, this paper therefore must be hereby marked advertise ment solely to indicate this fact.

${ }^{1}$ Institute of M olecular BioSciences, M assey $\mathrm{U}$ niversity, Private Bag 11 222, Palmerston N orth, N.Z.

${ }^{2}$ Institute of $\mathrm{N}$ atural Resources, M assey U niversity, Private Bag 11 222, Palmerston N orth, N.Z.

${ }^{3} \mathrm{D}$ epartment of $\mathrm{H}$ orticulture and $\mathrm{C}$ rop Science, $\mathrm{O}$ hio State U niversity, Columbus, $\mathrm{OH} 43210$
} 
problems and to transfer information to individual growers through workshops, newsletters and manuals. To maintain its effectiveness, the NZC C does not satisfy the needs of smaller growers at the expense of the larger, influential growers. $R$ ather, it seeks to the benefit the latter by upgrading the skill level of the industry, and by undertaking tasks too large for any individual business.

$\mathrm{N}$ ew Zealand flower growers traditionally have used a mild climate and the counter-seasonality of the southern hemisphere to supply lucrative export markets in the northern hemisphere during periods of peak demand. Since the early 1980s, N ew Zealand has experienced an unparalleled increase in the value of floriculture exports, with a growth of $1700 \%$ during 1981-86. World trade growth was $47 \%$ (U.S. $\$ 1.96$ billion) over the same period (Jamieson, 1990). Annual growth in flower exports was $22.1 \%$ in the decade to J une 1996.

This growth in floricultural exports was observed during a decade in which floriculture businesses entered a new era of deregulation. Firms were exposed to free and open competition in a perfect market. Rather than being subsidized to produce what was deemed to be good by government, firms had to produce what could be sold at a profit in any market. They had to purchase capital, run the business, and produce the goods without government guidance in the direction the business should follow. Ultimately, operating in a deregulated environment has meant being prepared to go out of business if the market did not support production of the crop. Successive conservativegovernmentssince 1984 havenot significantly altered this environment.

The market for callas (flower and tuber products from the southern African genus Zantedeschia) illustrates the growth that has occurred in the export of relatively new or exotic crops asopposed to traditional standard lines [e.g., roses (R osa L. hybrids), carnations (D ianthus caryophyllus L.), and chrysanthemums (C hrysanthemum xmorifolium Ramat)]. Callas are now the second largest flower export earner for $\mathrm{New}$ Zealand behind orchids (Cymidium Swartz), and followed closely by exports of other new crops [e.g., C hineselantern lilly (Sandersonia aurantiaca $\mathrm{H}$ ook)]. C allasrepresented $\approx 15 \%$ of the export market in recent years (Table 1; N ew Zealand D epartment of Statistics, 1992-97).

Thisgrowth hasled to an influx of new calla growers, who are either new entrants to the floriculture industry, or growers of more traditional flowers diversifying into newer flower crops. $\mathrm{N}$ ew calla growers were attracted by the growth in export volumes, which promised an opportunity for a more favorable return on investment than other floricultural or unrelated business ventures. Traditional barriers to entry, e.g., difficulty obtaining plant material and marketing restrictions, did not apply to growers who were changing to calla production. Currently, calla varietiesmost sought after on export markets are readily available becausethey are not protected by plant patents. There are also no restrictions on flower quantities produced, marketssupplied, or quality standards. The $\mathrm{N}$ ew Z ealand callaindustry, therefore, presents an excellent opportunity to document how a small primary industry sector has developed in an era of deregulation. Westudied thisindustry to prepare a description of the parties involved, their problems, and themethods being used to address these.

\section{Methods}

Preliminary interviews were carried out to identify industry parties and representative bodies. Semistructured interviews $(\approx 30)$ were then conducted during winter 1994 with executive members of three national flower industry bodies who had an interest in callas (listed below), staff of two active regional organizations, employees of two national research companies carrying out research on callas, and executives of the $\mathrm{New}$ Zealand Cutflower Exporters Association. Thoseinterviewed included owners of all the larger calla growing businesses, many of whom held executive office in one or moregrower organization. In addition, we at $M$ assey $U$ niversity conducted 20 face-to-face and 10 telephone interviews with calla growers holding no office with the several industry organizations. Interviews focussed on establishing each respondent's opinion of the key issues and problems facing the calla industry and his/ her business, e.g., perceived problems with industry organization, specific technological problemson his/ her property or with handling and marketing product, perceived research needs, and an assessment of performance of calla industry organizations.

$A$ random or stratified survey of thegrower population would not have been possible because of uncertainty about the number of calla growers (quoted by some respondents to be as high as 500) and addresses of their properties, and the lack of an official census of property sizes and outputs for those growers known to the research team. Collation and comparison of responses enabled the research team at $M$ assey $U$ niversity to judge that the interviewees had provided as complete a description of the calla industry as would be needed for the next part of the research, and that while the numbers interviewed were relatively small, they accounted for $>50 \%$ of export earnings. A draft position statement embodying this industry description was prepared from interviews, and circulated to all participantsfor comment. Thiswascorrected for errors of fact and transcription in light of feedback from respondents, and used in two calla industry workshops held in the capital (Auckland) during 1994 and 1995. Representatives of all known industry bodies attended both workshops, which were facilitated by the research team.

\section{Results}

Growers AND their ORganization. There are $\approx 20$ calla growers who are reputed to account for the majority (60\% to $70 \%$ ) of export earnings from callas. $\mathrm{M}$ any of these growers were associated with the calla industry since the early 1980's, and have gained a good understanding of the crop, its marketing and distribution. H owever, many of the $\approx 500$ callagrowersin $\mathrm{N}$ ew Zealand are either diversified flower growers having little experience with the calla crop, or are completely new to floricultural production and marketing. G rowers differed greatly in educational background and industry training, in their access to capital and in their attitudes to flower production in general.

M ore diversity was seen in the range of property size and location. Although the majority covered small areas $<1,000 \mathrm{~m}^{2}$ (0.25 acres), there was a small number of firms $(5 \%$ to $15 \%)$ that covered large areas $>10,000$ 
$\mathrm{m}^{2}$ (2.5 acres). C alla growers' properties were also geographically widespread, being located in one of twelve calla growing regions throughout the $\mathrm{N}$ orth I sland, and on the east coast of the South I sland of $\mathrm{N}$ ew Zealand (lat. $\left.35-43^{\circ} \mathrm{S}\right)$. Each growing region can be relatively isolated from other regions, and growers may be isolated within their own region. I nformation has not been collected by a government agency for someyears that would allow total area of calla production to be calculated.

Producers may be members of one or more of a diverse range of flower grower organizations. At the time this study was initiated, there were two national floriculture bodies (one with sector interest groups, including one for callas), regional floriculture groups (with some members who were highly knowledgeable calla growers), regionally organized calla grower groups who shared information specific to their geographic areas, and a nationally organized calla group ( $N$ ew Zealand CallaC ouncil (N ZCC), founded in 1991).

Grower organizationscompetefor members. Each may hold conferences, seminars and workshops, and produce written material and newsletters with varying degrees of emphasis on callas, typically without mutual consultation or coordination. N ot surprisingly, smaller and newer growers reported bewilderment at the array of organizations, not knowing which would give the greatest value for money and time spent at meetings. Because of the absence of national grower statistics, the number of calla growers that do not belong to any industry organization can only be estimated from anecdotal evidence. Calla growers who do not belong to an industry organization may account for a quarter of all calla producers.

Growers' problems. N eW Z ealand callagrowers have faced problemsarising from the withdrawal of government science and agriculture agencies from their traditional industry support roles. This is similar to the situation experienced by growers in Europe (Funt and Nicholson, 1991). A primary industrial research agency and an agriculture department (with a network of extension agents) existed up until the late 1980s. These were amalgamated, downsized and repositioned as crown research institutes (CRIS), and, in the case of the extension agents, privatized. Growers had fewer scientists working on strategic or applied research on callas, and extension advicewas available from moreexpensive private consultants. $\mathrm{N}$ ot as obvious has been the loss of the coordination and leadership these government agenciesonce provided. Growers now have organizational problems of defining, prioritizing and funding research projects, and disseminating results of funded research.

It is in this new context that calla growershaveto addressproduction and market related problems. G rowersneed accurate and timely market information to facilitate planning for successive seasons. A high level of technical skill and knowledge specific to callas is also needed, even for experienced flower growers. Particularlytroublesomeproblems are soft rot (Erwinia carotovora pv. carotovora) (Jones, 1981) in maturing calla tuber crops, pest infesta- tions, and postharvest disorders.

For sustained growth in export markets, calla growers need a continual supply of new cultivars. The cultivars used today are the result of breeding effortsstarted earlier thiscentury by noted horticulturists such as L uther Burbank in California, and continued during the 1960-80s by $\mathrm{N}$ ew Zealand breeders (Clemens, 1994). The value of this resource has been eroded as competitors in importing countries obtain and use the same or similar cultivars in their own production.

The diversity of grower experience, property location and size are also problematic. The experienced calla grower, the flower grower diversifying into callas, and the novice grower can have quite different perspectives of the relative importance of these problems. For instance, the small, novice grower may be concerned with crop production technology and gleaning sufficient information from exporters to be able to plan production. An experienced calla grower may focus more on new cultivar development and the refinement of crop scheduling for their particular growing environment. Although grower preference for technology transfer is via face-to-face contact, efficient delivery through discussion groups and seminars is hampered by the widespread location of calla production units and regions. Growers in each calla production region have to overcome local difficulties of flower consolidation and handling, and access to air transportation.

Solving Problems. D epending on resources at their disposal, growers

T able 1. Average value of $\mathrm{N}$ ew $\mathrm{Z}$ ealand floricultural exports per annum. ${ }^{\mathrm{Z}}$

\begin{tabular}{|c|c|c|c|c|c|c|c|}
\hline \multirow{3}{*}{$\begin{array}{l}\text { Flower } \\
\text { group }\end{array}$} & \multicolumn{6}{|c|}{$\$ 1$ Million/year } & \multirow{3}{*}{$\begin{array}{c}\% \\
\text { Total } \\
\text { floriculture } \\
\text { exports } \\
1995-97 \\
\end{array}$} \\
\hline & \multirow{2}{*}{\multicolumn{2}{|c|}{\begin{tabular}{l}
\multicolumn{2}{c}{$1989-91$} \\
NZ\$ (U.S.\$)
\end{tabular}}} & \multicolumn{2}{|c|}{ 1992-94 } & \multicolumn{2}{|c|}{ 1995-97 } & \\
\hline & & & $\mathbf{N Z \$}$ & (U.S.\$) & $\mathbf{N Z \$}$ & (U.S.\$) & \\
\hline Total floriculture & 19.90 & 10.55 & 35.11 & 18.61 & 46.64 & 24.72 & --- \\
\hline O rchid (C ymbidium sp. Swartz) & 9.14 & 4.84 & 15.52 & 8.22 & 18.49 & 9.80 & 40 \\
\hline N erine ( $\mathrm{N}$ erine samiensis L. H erb.) & --- & --- & $0.17^{y}$ & 0.09 & 0.56 & 0.30 & 1 \\
\hline Rose (R osa L. hybrids) & 1.40 & 0.74 & 1.54 & 0.82 & 0.79 & 0.42 & 2 \\
\hline Carnation (Dianthus caryophyllus L.) & 0.64 & 0.34 & 0.67 & 0.36 & 0.68 & 0.36 & 1 \\
\hline \multicolumn{8}{|l|}{ Chrysanthemum } \\
\hline (C hrysanthemum ×morifolium Ramat.) & 0.10 & 0.05 & 0.10 & 0.05 & 0.23 & 0.12 & 0.5 \\
\hline
\end{tabular}

zIn million dollars per year. NZ \$1.00 =U .S. \$0.53, M arch, 1999.

yStatistical information for nerine exports first available in 1992. 
solvetheir problems individually and/ or by requesting information from an organization to which they belong. Small growers are more dependent for production and market information on a strong, well-organized grower association, such as the NZCC. O ver the past 6 years, the NZCC, with the support of grantsfrom charitabletrusts and a voluntary levy of its members, has put extensive effort into providing advice to growers. I t has established a regular and comprehensive program of grower education and development through a periodic newsletter (including regional, exporter and research reports), seminarsand workshops. The NZCC also produced (and continues to update) a comprehensive growers' handbook (Clemens, 1994), and has funded research projects (e.g., on postharvest tuber soft rot) for itsmembers.

$L$ arge growers are in a better position than small growers to fund new research projects from their own resources. While they are reluctant to share intellectual property generated with their own funding, their influence on the shape of research and development, and interactions with consultants is of benefit to all growers. Large growers are also able to exert their influence on the selection of research contracts let by the government research foundation to the scientists in CRIs through membership in consultative committees and by serving as executives of growers' organizations. Through its educational program the NZCC indirectly benefits large growers by raising the overall quality of flowers and tubers and assisting in the funding of initiatives too costly for singlebusinesses of any size (e.g., trade fair exhibits).

\section{Discussion}

Fifteen yearsago there wasasingle flower growers' organization as described in the historically interesting thesis of I vess (1981). It was envisioned that theagriculture department, supported by the science agency of the time, would continue to coordinate discussion, provide support services and be "constantly available" to overcome growers' problems. The proliferation of grower organizations since then can, therefore, be seen as a result of the withdrawal of these centrally funded services, exacerbated by an influx of new and relatively inexperienced growers. Because membership of floricultural and calla sector associations is entirely voluntary, continued proliferation of organizations will depend primarily on growers' perception of the service provided by those organizations.

To judge by tangible outputs, such as the production of the calla growers' handbook and the funding of technological research, the NZCC is providing industry leadership for research and information. The NZCC has been the most successful calla organization since its inception when the $\mathrm{N}$ ew Z ealand T rade D evelopment Board (NZTDB) recognized the potential of callas for export growth and provided seeding money for its foundation. Possibly because of the favor shown the NZCC during its establishment by the N ZTDB, its dominance is continually challenged by smaller organizations that competefor attention through local focus, networksand provision of information. At the second calla industry workshop organized by the authors, it was apparent that executives of some calla organizations preferred the status quo of apparent industry disorganization, indicating that grower choice of organization was an essential vitalizing element in a dynamic industry. Given the climate of change that continues to sweep the country, it is highly likely that the N ZCC will need to make a sustained effort to serve its members in order to maintain its membership and effective leadership.

The ability of the NZCC to continue to provide leadership for calla growers will also depend upon how strongly growers believe they need a unified agency to tackle issues that transcend individual grower problems. These include interactions with research scientists and the government research foundation, negotiationswith exporter associations and export regulatory authorities, and the formulation of astrategy for achieving further overall industry growth on export markets. Interestingly, flower growers in the early 1980s expected the government to press for a marketing board for floricultural exports (as with pipfruit and dairy products), although apparently therewasno such intention on its part (I vess, 1981). In the absence of such a marketing board, the strength of an organization such as the N ZCC (or its replacement) is critical to advocate the needs of individual growers.
The success of the N ZCC could become more important to growers if the government research foundation budget for funding research on technological problems of callas is further reduced. The views of leaders of other primary export industries are important in this context. These influential people tend to believe that research and development investment should betargeted not at growers but at those closer to end markets (e.g., value adding processors, and exporters) (Baker, 1995).

The issue of effective communication between the grower associations such as the NZCC and scientists in CRIS is one that is currently being studied. An important triangular relationship exists between grower associations, the scientists carrying out research funded by the government in the CRIs("public good" science), and the government research foundation that funds public good science. G rowersare consulted through their organizations on how limited science dollars should be spent nationally; the science providers bid for contracts with the foundation, and the results of the research are communicated to the growers and their organizations. In due course the growers, if satisfied with progress, support the scientists in their efforts to obtain further research dollars.

Contracts with the government research foundation have detailed specifications that CRIs must fulfill. The research foundation has detailed procedures for fulfilling its requirement to consult on the broad areas of research to fund. H owever, while scientists in CRIs may carry out specific technology transfer activities (e.g., publish papers, write trade articles, and talk at industry meetings), effectivecommunication between thesetwo parties is often questioned. There is a general perception (perhaps common to most sectors) that grower organizations do not get good value for money from public good research carried out by scientists.

For public good research supporting the calla export industry to be successful, there has to be effective two-way communication between scientists and the N ZCC. To thisend the N ZCC recently employed the services of a science liaison officer. This novel approach was adopted in part to augment the efforts of scientists to com- 
municate the meaning of their experimental results. It is intended that the progress of individual research projects can be effectively monitored by the N ZCC. Of greater significance is the expectation that the liaison officer will continually communicate the needs of growers to scientistsso that bids to the government for research funding can more accurately reflect grower needs. The success of this initiative remainsto be assessed.

Continued input of government funds for floricultural research will depend on the demonstration that science results are being used by growers to the benefit of the public of $\mathrm{New}$ Z ealand. N ovel approachesto improve communication are needed, such as the proactive initiative being taken by the NZCC to enhance communication between itself and scientists. With respect to communication between growers and their organizations, the traditional means, such as workshops and newsletters, remain the principal channels. While a move on the part of growers-many of whom come from industrial or business backgroundsto join electronic discussion groups such asthosedescribed by $V$ an $V$ ranken and Cowgill (1996) could be anticipated, the vast majority of growers in $\mathrm{N}$ ew Zealand do not as yet use personal computersfor any purpose other than accounts and stock management.

In conclusion, we observed that thefreedom to becomea $\mathrm{N}$ ew Z ealand grower and exporter of callas hashad a detrimental impact on the ability of growers to invest in and select appropriate research. It has hindered efforts to have a unified sector organization, and to provide an effective technology transfer mechanism to a diverse and widespread group of growers. In this regard, there is a stark contrast between the calla sector and that of a successful group of growers exporting nerine flowers. The nerine (from the southern African genus Nerine W. Watts, family Amaryllidaceae) is another "new" floricultural crop showing export potential ( $\mathrm{New}$ Zealand $\$ 0.68$ million in 1996) with a rich genetic resource gathered and bred within N ew Zealand. U nlike the situation for callas, the nerine genetic resource tends to be tightly controlled, with a close-knit network of growers who are bound to each other's success by contract. The latter may be a more appropriate sector model in an increasingly competitive floricultural marketplace.

\section{Literature cited}

Baker, C. Alma T rust. 1995. M ethodologies for linking funders, researchers and end users. Publ. 14. C. Alma Baker Trust, Wellington, N.Z.

Clemens, J . (ed.). 1994. The N ew Zealand Calla Council growers' handbook. N.Z. Calla Council, Wellington.

Funt, R.C. and J.A.H . N icholson. 1991. Comparison of grower adviso ry systems in Europe. H ortScience 26:103-105.

I vess, R.J. 1981. Situation analysis of the $\mathrm{N}$ ew Zealand export cut flower and cut foliage industry. DipBusAdmin thesis, M assey U niv., Palmerston N orth, N .Z.

Jamieson, M. 1990. Developing the competitive advantage of $\mathrm{N}$ ew Z ealand: Porter process. Ernst and Young, Wellington, N.Z.

New Zealand Department of Statistics. 1992-97 (annual). O verseas trade statistics. N .Z. D ept. Stat., Wellington.

Van Vranken, R.W. and W.P. Cowgill, Jr. 1996. Using electronic mail discussion groupson theinternet to enhance communication in specific commodity groups. H ortT echnology 6:318-324. 